\title{
The Research on the Realization Path of College Students' Employment Ideological and Political Education*
}

\author{
Ningjun Wang \\ Northwestern Polytechnical University \\ Xi'an, China 710072
}

\author{
Li Wang \\ Northwestern Polytechnical University \\ Xi'an, China 710072
}

\begin{abstract}
The ideological and political education plays a vital role in the employment of University Students. With the severe employment situation, it is more practical to explore the path of ideological and political education in employment. By establishing one central idea of a student-centered concept, with the three-party power of universities, families and students, through four channels of online classroom, offline classroom, social practice and campus simulation, we finally realize the two goals of enhancing the quality of employment and strengthening the ideological and political education of employment. This is our "one center, two goals, three guarantees, four channels" analysis of the realization path of the university students ' employment ideological and political education.
\end{abstract}

Keywords-employment; ideological and political education; realization path

\section{INTRODUCTION}

The 2016 National Conference on Ideological and Political Work in Colleges and Universities pointed out: "We must persist in taking high moral values establishment and people cultivation as the central link, and carrying out ideological and political work throughout the entire process of education and teaching, to realize educating people in the whole process and in all directions, and strive to create new developments in China's higher education." The 19th CPC National Congress Report stated: "The whole party should care for and protect young people, accelerate the construction of first-class universities and first-class disciplines, provide a full range of public employment services, and promote multi-channel employment and entrepreneurship among college graduates and other youth groups." The Ministry of Education also clearly stated in the "Notice on Strengthening the Ideological and Political Education of Employment of Students in Regular Colleges and Universities": " Colleges and universities should establish and improve the management system and working mechanism combining students' ideological and political education with employment, and give full play to the positive role of ideological and political education in guiding and promoting student employment." The party and the state attach great importance to the ideological and political education and employment of college students. Strengthening the college

*Fund: Policy and Strategy Research Fund of Northwestern Polytechnical University (2018ZCZ04) students' employment ideological and political education has become one of the important contents of the ideological and political education of college students in the new era. It is directly related to the growth of college students and the harmonious development of society.

\section{ThE MEANING OF COLLEGE STUdENTS' EMPLOYMENT IDEOLOGICAL AND POLITICAL EDUCATION}

The college students' employment ideological and political education is that the education subject applies the idea of employment to the education object in a specific way according to specific purposes, in order to help the education object to establish a correct employment view. Understanding the connotation of college students' employment ideological and political education needs to define the three concepts of college students' ideological and political education, employment view and employment guidance.

College students' ideological and political education is a social practice of colleges and universities to train college students into qualified builders and reliable successors with socialism with Chinese characteristics, based on the overall requirements of social development, in an organized way, purposefully and designedly [1]. The process includes four basic components: educators, educatees, educational mediators, and educational circles.

The employment view refers to the tendency of career choices displayed by college students with the guidance of selfideality, taking into account social needs and self-development. This concept is a comprehensive reflection of college students' outlook on life and values on employment issues [2]. It is a certain degree of social consciousness, composed of three elements: emotion, cognition and behavioral tendency [3].

Employment guidance, also known as "vocational guidance," was first proposed by American scholar Frank Parsons. The American Vocational Guidance Association interprets employment guidance as a process to help students choose a job. There are broad and narrow definitions of the meaning of employment guidance in academia: the broad definition of employment guidance generally refers to providing relevant information, job skills training, and counseling and service for job seekers from three perspectives: selecting a job, getting a job, and adapting to a job, in order to 
help them to get jobs; the narrow definition of employment guidance refers to the transfer of employment information to job seekers, and help in the employment process of job seekers.

\section{The Status QuO of COLlEGE STUdents' IDEOLOGICAL AND POLITICAL EDUCATION}

\section{A. The Effect of College Students' Employment Ideological and Political Education}

College students' selecting employment, obtaining employment and vocational development are directly related to people's livelihood, which is of great significance to the stability of the whole society, the sustainable development of the national economy and the realization of a beautiful and happy Chinese dream [4]. The correct employment view is the guiding light for college students' employment. It can guide college students to guide their behavior with correct consciousness, and at the same time play an important role in employment. Under the increasingly severe employment situation, the role of ideological and political education in the employment of college students has become more and more prominent. Various colleges and universities have also set up employment committees to strengthen vocational development education and employment guidance for students, help students establish a correct employment view and job-choosing view, and pay attention to ideological and political education in the process of employment guidance, thus achieving the organic combination of student employment and ideological and political education, which has achieved good results.

1) The understanding of employment ideological and political education is gradually deepening: The convening of the National College Ideological and Political Conference provided an opportunity for the in-depth development of employment ideological and political education. All colleges and universities comprehensively implemented the party's education policy, firmly established the concept of peopleoriented education, moral education comes first, and attached great importance to the role of ideological and political education in the employment of college students. They not only increased their investment in hardware and software facilities, but also introduced a series of policies and measures to strengthen the college students' employment ideological and political education. At the same time, colleges and universities have strengthened the employment guidance and vocational development education for students by offering relevant courses such as "Career Planning for College Students" and "Employment Guidance". The employment guidance center and psychological counseling center of colleges and universities have actively integrated ideological and political education into the practice of helping students with employment difficulties, and have done a lot of fruitful work.

2) The content and methods of employment ideological and political education are more diverse: In order to adapt to the employment situation, the content and methods of ideological and political education in colleges and universities in employment guidance are more diverse, richer and more practical. The teaching content of the employment courses is more substantial and the teaching methods are more flexible and changeable. By understanding the students' employment intentions and testing their psychological status, the education subject continuously enriches the educational content to help the education object to establish a correct outlook on life and values, which has achieved good results. According to the "Report on the Development of Chinese College Students' Ideological and Political Education 2016", the current ideological and political situation of college students shows a good development trend, and $66.4 \%$ of college students agree that "dedication is the greatest happiness in life" and that individual value should not be above social value. More than $60 \%$ of students tend to find a balance between the two when answering the relationship between individual value and social value. The survey shows that most college students have a positive outlook on life, and they highly agree with the socialist core values and have a firm political ideal and belief, which have a positive impact on the college students' employment.

\section{B. Problems in the College Students' Employment Ideological and Political Education}

Although ideological and political education has played an obvious role in employment in recent years, there are still some problems in real life due to many factors. Mainly manifested in:

1) The content of employment ideological and political education in colleges and universities is less targeted: At present, many colleges and universities gradually pay attention to the role of ideological and political education in the employment process, and continue to enrich the content of education. However, in light of the current employment situation, the measures of colleges and universities still cannot meet the needs of students. The employment guidance of most colleges and universities focuses on policy promotion, job search skills and other aspects, and is mainly for senior students, and the course format is limited to special topic lectures and job fairs, etc. Although some colleges and universities have setup courses related to employment guidance, they still exist such as lack of formal teaching materials, less class hours, empty content and other problems. They also have less education on employment view, jobchoosing view, employment psychology and others, which cannot attract students' interest. In addition, when carrying out employment ideological and political education, colleges and universities mainly rely on the traditional centralized teaching mode, of which the content of the lectures focuses on the situational policy education such as world view, outlook on life, values and professional ethics. This kind of education is separated from the actual needs of students and society, and it is impossible to carry out hierarchical and planned guidance according to the different characteristics of students.

2) The participation of family in employment ideological and political education is low: Employment ideological and political education must rely not only on the strength of 
colleges and universities but also on family participation. However, in reality, many families pay less attention to the employment ideological and political education, their main concern is the location and nature of students' choice of employment. Many parents tend to let their children work in the first-tier cities rather than at the grassroots level and they despise the graduates who choose to work in the countryside. For the parents' expectations, the children's participation in the "basic project" and "self-employment" proposed by the state is low. They dare not try boldly, so they can only choose to stay in the city with heavy burdens, which greatly reduces the job-seeking scope of students. Moreover, parents pay less attention to their employment psychology and employment view in the process of their children's employment, and even discriminate against some works.

3) Individuals' acceptance of employment ideological and political education is low: Employment ideological and political education is a long-term process. Due to the impact of the market economy, many college students are pursuing the principle of "efficiency first". When they choose a occupation, they pay more attention to their own value and themselves, excessively pursue the salary of the work, and less think about the embodiment of social value. In addition, the content of employment ideological and political education courses offered by many colleges and universities is relatively poor, boring and untargeted, rarely combined with the needs of students, and many are deviated from the actual situation, which often leads to students lack of interest in employment ideological and political education courses, and even get bored of it.

\section{ANALYSIS ON THE REALIZATION PATH OF COLLEGE STUDENTS' EMPLOYMENT IDEOLOGICAL AND POLITICAL EDUCATION}

The employment ideological and political education for college students is a long and tortuous process. It is necessary to establish a student-centered concept, to use the common strength of colleges and universities, families, and students, and through online classrooms, offline classrooms, social practice, and campus simulation to finally achieve the goal of improving the quality of employment and strengthening the employment ideological and political education, as can be seen in "Fig. 1" in order to actively explore the scientific and effective realization path of college students' employment ideological and political education.

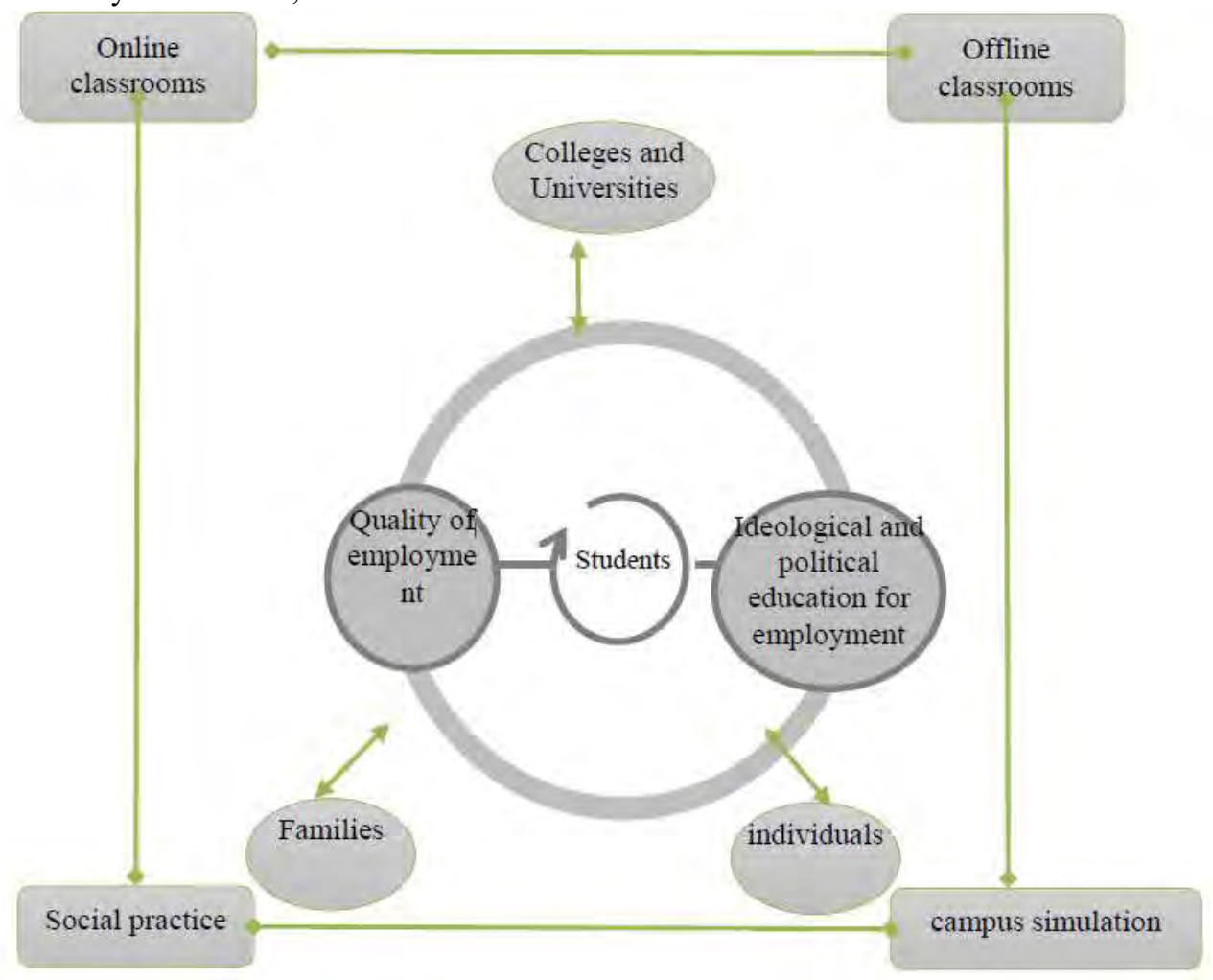

Fig. 1. Map of the Realization Path of College Students' Employment Ideological and Political Education.

\section{A. One Center - Student-centered}

Strengthening the college students' employment ideological and political education should establish a student-centered concept, promote students' all-round development, give full play to students' creativity, cultivate students' independent thinking ability, focus on improving students' comprehensive quality, and educate and guide students from different aspects, enrich and meet the spiritual and material needs of students, and help students achieve self-worth; at the same time, it must enhance students' cognitive ability, judgment ability and practical ability, so that they can accurately grasp the characteristics of things and the relationship between things, cultivate students' career 
planning and vocational development awareness, and strengthen their subjective initiative and sense of ownership in employment.

\section{B. Two Goals - Improving the Quality of Employment and Strengthening Ideological and Political Education for Employment}

The quality of employment directly reflects the quality of talent cultivation, which is an important condition for colleges and universities to attract excellent students. The improvement of employment quality is closely related to the acceptance and practice of students' ideological and political education. Strengthening the college students' employment ideological and political education should aim at improving the quality of employment and strengthening the employment ideological and political education, by strengthening employment ideological and political education, combining solving practical problems with solving ideological problems, carry out ideological and political education throughout the whole process of education and teaching, to effectively solve the employment problems of students, and strive to improve the quality of employment.

\section{Three Guarantees - Colleges and Universities, Families, Individuals}

Strengthening the college students' employment ideological and political education should give full play to the role of colleges and universities, families and individuals, and carry out ideological and political education throughout the whole process of student employment.

1) Colleges and universities: Because there are problems in the employment ideological and political education, such as the content of education is less targeted and the educational methods need to be innovated, colleges and universities should pay attention to constructing a scientific and reasonable educational content system, and carry out ideological and political education for students in stages. Colleges and universities should carry out educational activities according to the characteristics of students in different grades, integrate employment ideological and political education into the students' college career, and educate students on employment view, jobchoosing view and employment psychology as early as possible to help students understand the majors in a comprehensive and in-depth manner at the beginning of the school year, correctly understand the relationship between personal values and social values, and establish a correct employment view. In addition, colleges and universities should also pay attention to enriching the content of employment guidance courses, adding employment ideological and political education content, fully integrating students and social development needs, and increasing the proportion of employment view, job-choosing view and employment psychology education for different types of students; it is also necessary to innovate educational methods, change the traditional centralized teaching mode, and actively explore new employment ideological and political education methods.

2) Families: Family is an important factor in the work of employment ideological and political education. Parent education has a significant impact on the employment view and job-choosing view of children. When carrying out employment ideological and political education, colleges and universities should actively communicate with parents of students, mobilize parents to cooperate and support employment ideological and political education, and should also help parents to change their job-choosing view, broaden their horizons, to correctly understand the current employment situation and strengthen the psychological construction that all jobs are equal, in order to make parents calmly look at the problems that children have in the process of employment, respect their children's career choices, encourage their children to actively face the setbacks and the force majeure factors that arise in the process of employment, and encourage children to choose jobs in multiple directions, not limited to the narrow scope defined by parents, which will provide a strong guarantee for the children to face a competitive and challenging workplace environment in the future.

3) Individuals: Students are not only the object of employment ideological and political education, but also the subject of employment ideological and political education. In the process of employment ideological and political education, students should actively play their role as a subject to achieve self-education and self-management, including self-regulation, self-learning and selfencouragement. Through self-learning, students can acquire methods and skills to solve problems, develop good study habits, and choose suitable learning content and methods. When encountering setbacks in the employment process, students should learn to adjust themselves to avoid extreme phenomena in their psychology. Students should correctly recognize and affirm their own values, carry forward the spirit of "self-confidence, self-reliance, self-respect, and self-improvement", and comprehensively understand their own strengths and weaknesses, in order to provide conditions for cultivating a correct employment view and job-choosing view.

\section{Four Channels - Online Classroom, Offline Classroom, Social Practice, Employment Simulation}

Due to the difficulty in carrying out employment ideological and political education, it is necessary to integrate resources in various fields, broaden educational channels, rationally use online and offline resources for teaching in theory, and carry out social practice and employment simulation to strengthen practical education.

Along with the development of the Internet era, the form of employment ideological and political education has also undergone new changes. In carrying out employment ideological and political education, colleges and universities 
should make full use of the online platform, combine students and social development needs, and employ employment ideological and political education as the theme to provide diverse educational content for different students, such as helping introverted students to enhance their social skills and job-hunting skills ; providing entrepreneurial opportunities for students who want to start their own businesses, helping them enhance their entrepreneurial skills; providing employment prospect of corresponding major and skills training required for employment for students who want to work, etc. The rapid development of the Internet platform cannot replace the role of offline classrooms, because students can communicate face-to-face with teachers in the classroom, which plays the role of ideological and political education theory. Incorporating ideological and political education into other courses offered can help students establish lofty career aspirations and enhance their sense of mission and responsibility.

Social practice is an important link in the employment ideological and political education. Through the implementation of social practice activities, colleges and universities can enable students to correctly understand the society, experience the spiritual strength of hard struggle, and cultivate students' team consciousness, collective consciousness and cooperative consciousness [5] to improve students' ability to live independently. Colleges and universities should build a social practice platform for students and encourage students to participate in social practice and volunteer activities, and lead students to choose the right career direction that suits them. In addition, colleges and universities can also carry out educational work through campus simulation activities, including creating career planning competitions, simulating job fairs and other diverse activities to enhance the effectiveness of employment ideological and political education.

\section{CONCLUSION}

The ideological and political education in the process of college students' employment is very important. Strengthening the college students' employment ideological and political education is related to the growth of college students and the harmonious development of society. Strengthening vocational development education and employment guidance for students, helping students to establish a correct employment view and job-choosing view, and paying attention to ideological and political education in the process of employment guidance is a realistic need to solve employment difficulties. Employment should be student-centered, with the power of colleges and universities, families, and students, through online classrooms, offline classrooms, social practice, and campus simulation to ultimately improve the quality of employment and strengthen employment ideological and political education. The realization path of college students' employment ideological and political education of "one center, two goals, three guarantees and four channels", playing the role of college and university, family and individual and integrating the ideological and political education into the whole process of student employment, can effectively solve the employment problems of students and improve the quality of students' employment.

\section{REFERENCES}

[1] Li Shouxiang. Research on Ideological and Political Education in College Students' Employment Guidance [D].Hebei Normal University, 2012 (in Chinese)

[2] Luo Jianqin. Education of College Students' Employment View under the Popularization of Higher Education [J].Theory and Contemporary, 2005(3):17-18 (in Chinese)

[3] $\mathrm{Hu}$ Weifang. Research on the Characteristics, Causes and Countermeasures of the "90s" College Students' Employment View in the Post-Crisis [J].Qinghai Social Sciences, 2010(6):2-75. (in Chinese)

[4] Tang Zixi, Wang Xianping. Comparison and Analysis of College Students' Employment Ideological and Political Education in Different Periods since the Reform and Opening-up[J].Journal of Ideological and Theoretical Education,2014(3). (in Chinese)

[5] Dong Wei. A Brief Discussion on the Methods of College Students Ideological and Political Education under the New Employment Situation [J]. Contemporary Education Practice and Teaching Research, 2017(8). (in Chinese) 